\title{
The microbiology and pathogenesis of infective endocarditis
}

\author{
RICHARD BAYLISS, CYRIL CLARKE, C M OAKLEY, W SOMERVILLE, \\ A G W WHITFIELD, S E J YOUNG
}

From the Medical Services Study Group of the Royal College of Physicians, the British Cardiac Society, and the Comemunicable Disease Surveillance Centre, London

SUMMARY Some details of 544 episodes of infective endocarditis occurring in 541 patients during 1981 and 1982 are reported. The mean age of patients was 51.6 years and there was a greater proportion of males $(2: 1)$. Of the 544 episodes $347(63 \%)$ were due to streptococci, $19 \%$ to staphylococci, and $14 \%$ to bowel organisms. A wide variety of other organisms were responsible for a few cases, and $10 \%$ were culture negative. In $60 \%$ the portal of entry of the infection could not be ascertained: $19 \%$ were probably of dental origin: $16 \%$ arose from the alimentary, genitourinary, or respiratory tracts or from the skin or in association with drug addiction, fractures, or pregnancy; the remaining $5 \%$ were related to cardiac or other vascular surgery, cardiac catheterisation, haemodialysis, or other procedures involving the blood stream. Seventy-four (14\%) of the 541 patients (mean age 59.0 years) died; the mortality was $30 \%$ in staphylococcal cases, $14 \%$ in infections due to bowel organisms, and $6 \%$ in other streptococcal infections. One hundred and seventy-one (32\%) of the patients appeared to have had normal hearts before the onset of illness and another 59 (11\%) had cardiac lesions not previously recognised. The aortic valve was the most common site of infection. Ninety (17\%) of the patients had prosthetic valves or had undergone other cardiac surgery while $34(6 \%)$ had had a previous episode of infective endocarditis. Nine (1.6\%) episodes were not diagnosed until necropsy or operation and $34(6.3 \%)$ required urgent valve replacement.

Since Horder's classic description of infective endocarditis nearly three quarters of a century ago $^{1}$ antibiotics and valve replacement have transformed the then hopeless prognosis. Studies have shown a changing pattern of the disease, ${ }^{2-9}$ but despite the enormous advances in microbiology, particularly the speciation of the streptococci, the source of the infection is often not known and the proportion of cases related to dental procedures or sepsis is probably smaller than previously believed. A recent study of 541 patients with infective endocarditis with particular reference to dental prophylaxis has confirmed this. ${ }^{10}$ The number of patients studied was so large compared with previous reports that we considered it appropriate to present some of the other findings in respect of microbiology and pathogenesis.

Accepted for publication 26 July 1983

\section{Patients and methods}

The investigation covered two years, and the British Cardiac Society and the Medical Services Study Group of the Royal College of Physicians endeavoured, with the help of fellows and members of the college, to study all patients with infective endocarditis in the British Isles during 1981 and 1982. A short proforma was used with the main object of ascertaining the incidence of cases of dental origin and the efficacy of dental prophylaxis. There was a considerable shortfall in reporting, but a survey of the hospitals staffed by physicians and cardiologists who did contribute does not suggest any significant bias in the sample and we do not believe that the unreported cases would affect the validity of the conclusions presented. 
Table 1 Causal orgarism in 544 episodes of infective endocarditis

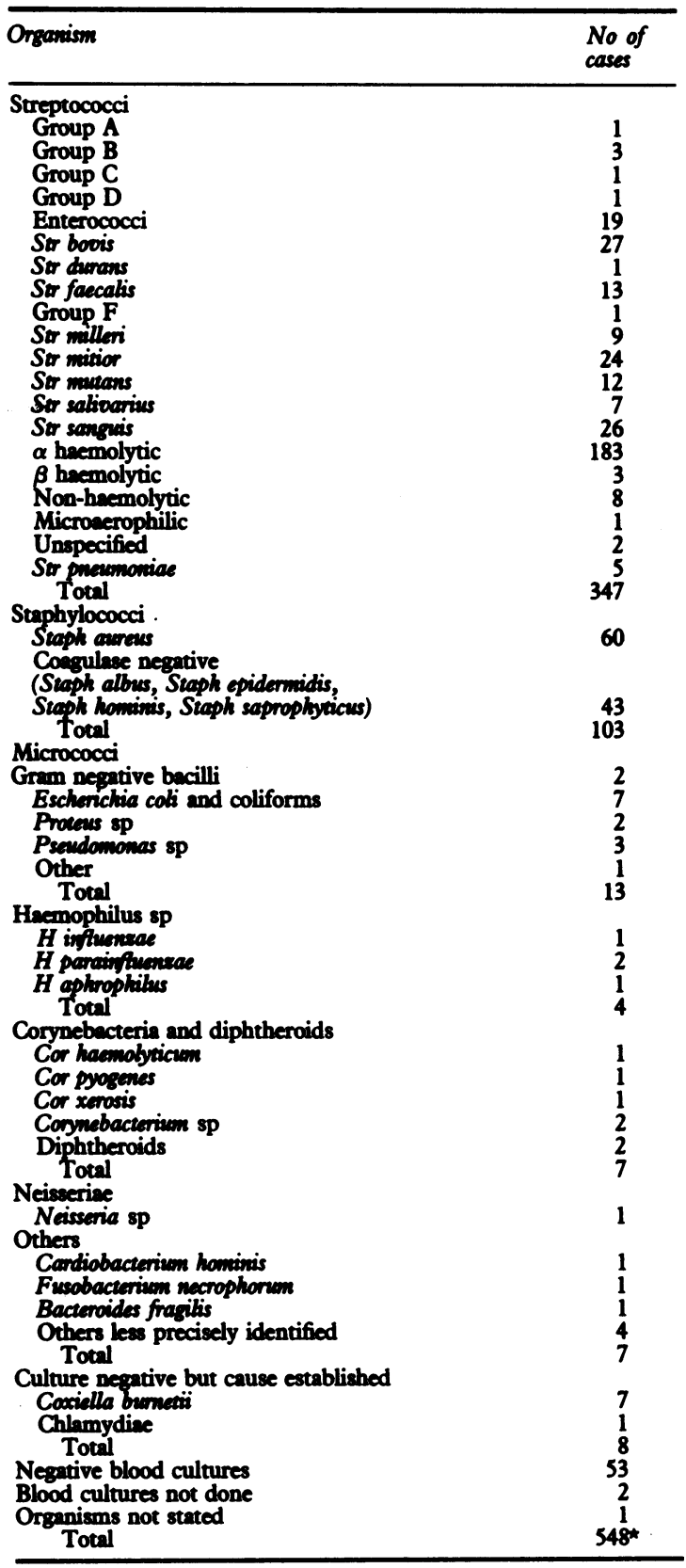

^In four episodes two organisms were cultured.

\section{Results}

A total of 544 proformas were received concerning 541 patients, three of whom had two episodes of infec- tive endocarditis in the two years. The age range of the patients was 2-87 years (mean age 51.6) and there was a greater proportion of males (ratio 2:1).

Table 1 shows the causative organisms grown on blood culture or otherwise, and Table 2 gives their source, as far as this could be ascertained. In four episodes more than one organism was cultured. Seventy-four (14\%) of the 541 patients died, and brief clinical details are given in Table 3 .

Table 4 shows the primary cardiac abnormalities in the 541 patients. Instances in which the doctors, dentists, and patients themselves were unaware of the presence of a pre-existing lesion are also shown, as are patients with previously normal hearts. The valve, valves, or other sites affected by endocarditis, as far as they are known, are shown in Table 5. Table 6 summarises the factors predisposing to infective endocarditis in the 544 episodes, and Table 7 gives details of the 77 patients with prosthetic valve endocarditis. In five patients the diagnosis was not made until necropsy and in another four not until operation. Thirtyfour patients required emergency valve replacement.

\section{Discussion}

The mean age of the patients was high ( 51.6 years), a trend indicated in many recent reports. 34689 Twenty-two of the 541 patients were 15 years of age or less, and 21 of them had known congenital heart disease. By contrast there were 155 patients aged 65 and over, and in 59 of these there was no evidence of any pre-existing cardiac abnormality. Among Horder's ${ }^{1}$ 150 cases there were only 12 over the age of 50 , and 30 years ago most of Cates's and Christie's ${ }^{2}$ patients were between the ages of 15 and 35, but only $13.7 \%$ of the 541 reported here were in this age range. Several factors doubtless contribute to this change, the decreasing incidence of rheumatic heart disease and the greater longevity of the population being among the most important. There was a greater proportion of

Table 2 Source of causal orgarism in 544 episodes of infective endocarditis

\begin{tabular}{lr}
\hline Poesibly dental & 103 \\
Alimentary tract & 22 \\
Genitourinary tract & 23 \\
Reepinatory tract & 17 \\
Skin & 14 \\
Drug addiction & 6 \\
Fractures (3 compound, 1 closed) & 4 \\
Pregnancy and parturition & 3 \\
Related to cardiac operations, non-cardiac vascular procedures, \\
cardiac catherisation, venograms, blood donation, anticoagu- \\
lant treatment or chronic haemodialysis \\
No portal of entry apparent & 26 \\
Total & 326 \\
\hline
\end{tabular}


Table 3 Details of the 74 patients who died from infective endocarditis

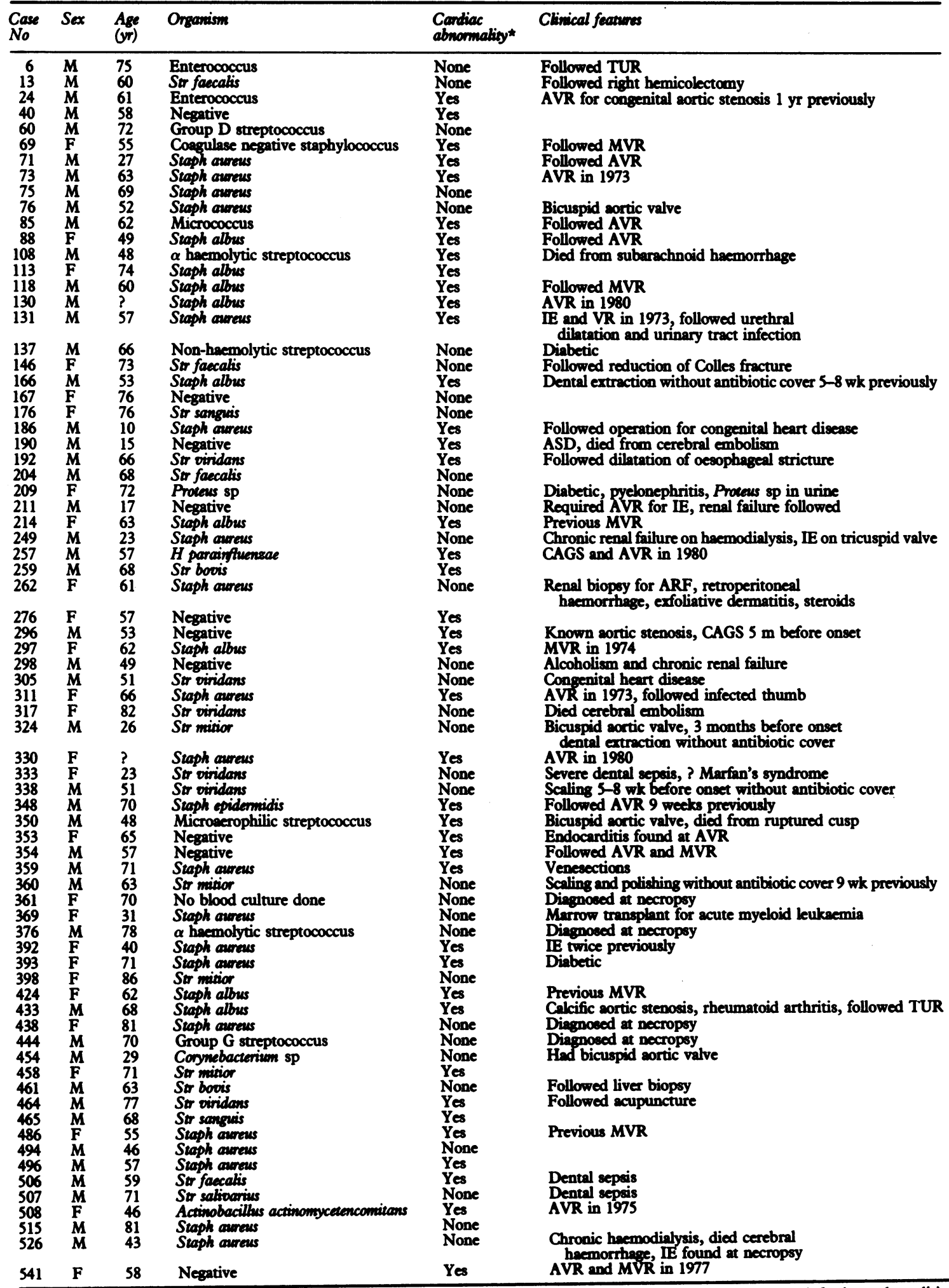

^Previously known. TUR, transurethral resection; AVR, aortic valve replacement; MVR, mitral valve replacement; IE, infective endocarditis; CAGS, coronary artery graft surgery; ARF, acute renal failure. 
Table 4 Primary cardiac abnommalities of the 541 patients with 544 episodes of infective endocarditis

\begin{tabular}{|c|c|c|}
\hline & $\begin{array}{l}\text { Known before } \\
\text { onset of IE }\end{array}$ & $\begin{array}{l}\text { Not known before } \\
\text { onsed of IE }\end{array}$ \\
\hline $\begin{array}{l}\text { Rheumatic heart disease } \\
\text { Congenital heart discase } \\
\text { Other cardiac abnormality }\end{array}$ & $\begin{array}{r}116^{*} \\
76^{*}\end{array}$ & $\begin{array}{l}10 \\
23\end{array}$ \\
\hline $\begin{array}{l}\text { (for example, mitral valve prolapse, calcific artic valve disease) } \\
\text { No apparent cardiac abnormality } \\
\text { Not stated } \\
\text { Total }\end{array}$ & $\frac{115^{\star}}{311}$ & $\frac{26}{171}$ \\
\hline
\end{tabular}

*These figures include 90 who had had valve replacement or other cardiac surgery before the episode of infective endocanditis studied and 34 who had previously had infective endocarditis (Table 6).

IE, infective becterial endocarditis.

Table 5 Valve or other site affected by infective endocarditis in 544 episodes

\begin{tabular}{lr}
\hline Aortic valve & $142^{\star}$ \\
Mitral valve & $119^{\star}$ \\
Aortic and mitral valves & $24^{\star}$ \\
Tricuspid valve & $6^{\star}$ \\
Tricuspid and mitral valves & $3^{\star}$ \\
Tricuspid and sortic valves & $1^{\star}$ \\
Tricuspid, mitral, and artic valves & $1^{\star}$ \\
Pulmonny valve & 1 \\
Congenital heart lesion & 46 \\
Pecemaker & 2 \\
Uncertain & 199 \\
Total & 544 \\
\hline
\end{tabular}

ऋThese figures include 77 patients with prosthetic valves.

Table 6 Factors predisposing to infective endocarditis

\begin{tabular}{lc}
\hline Prosthetic valves & 77 \\
Other cardinc surgery & 13 \\
Previous infective endocarditis & $34^{*}$ \\
Drug addiction & 6 \\
Dinbetes & 8 \\
Alcohol dependence & 4 \\
Immunosupprestion & 8 \\
Rend failure with or without haemodialysis & 7 \\
\hline
\end{tabular}

*Includes nine of the $\mathbf{7 7}$ who had had valve replacements.

males, another trend indicated by most recent writers. 4681112 The reasons for this are uncertain, although it may be related to the higher incidence of bicuspid aortic valves and calcific aortic stenosis in males and to the diminishing importance of rheumatic heart disease, which is more common in females.

The causal organisms (Table 1) were streptococci in $63.3 \%$, staphylococci in $18.9 \%$, and organisms probably originating from the bowel in $14 \% ; 75.5 \%$ of the streptococci were of the viridans group. In $10 \%$ blood cultures were negative or not done. These findings are in general agreement with other recent series. ${ }^{689}$

The portal of entry to the blood stream of the causal organisms is much more difficult to identify (Table 2). In $60.3 \%$ of the 544 episodes there was no clue, and though in 122 of the episodes the patient had dental sepsis or had undergone a dental procedure with or
Table 777 patients with prosthetic valve endocarditis

\begin{tabular}{|c|c|c|}
\hline & $\begin{array}{l}\text { Earty } \\
\text { endocarditis* }\end{array}$ & $\begin{array}{l}\text { Late } \\
\text { endocarditist }\end{array}$ \\
\hline $\begin{array}{l}\text { Number } \\
\text { Mean age (years) } \\
\text { Mortality. } \\
\text { Previous infective endocarditis }\end{array}$ & $\begin{array}{l}11 \\
46.9 \\
45 \%\end{array}$ & $\begin{array}{l}66 \\
52.9 \\
21 \% \\
9\end{array}$ \\
\hline $\begin{array}{l}\text { Staphylococci } \\
\text { Micrococci } \\
\text { Corynebecteria and diphtheroids } \\
\text { Str oinidans }\end{array}$ & $\begin{array}{l}84 \\
1 \\
1 \\
1 \neq\end{array}$ & $\begin{array}{r}21 \\
2 \\
2 \\
16\end{array}$ \\
\hline $\begin{array}{l}\text { Bowel organisms } \\
\text { Other organisms } \\
\text { Negative cultures } \\
\text { Negative-Coxiella bumetii }\end{array}$ & 1 & $\begin{array}{r}6 \\
6 \\
10 \\
3\end{array}$ \\
\hline $\begin{array}{l}\text { Valves: } \\
\text { Mitral } \\
\text { Aortic } \\
\text { Mitral and aortic } \\
\text { Mitral and tricuspid } \\
\text { Mitral, aortic, and tricuspid } \\
\text { Aortic and tricuspid } \\
\text { Tricuspid } \\
\text { Uncertain }\end{array}$ & $\begin{array}{l}3 \\
5 \\
3\end{array}$ & $\begin{array}{r}24 \\
25 \\
8 \\
2 \\
1 \\
2 \\
1 \\
3\end{array}$ \\
\hline
\end{tabular}

\#Within eight weeks of insertion of prosthetic valve. Hore than eight weeks after insertion of prosthetic valve. \$Two patients' blood grew two organisms.

without antibiotic cover during the three months before the onset of illness, the relevance of this history is uncertain because a dental background of this pattern is much the same as that of those enjoying normal health. ${ }^{10}$ Nevertheless, in 103 of the 122 cases a dental origin was probable. The importance of infective, malignant, and other lesions in the alimentary, genitourinary, and respiratory tracts and the procedures used in their investigation and treatment in the causation of infective endocarditis is much more firmly established, $34812-16$ as are cutaneous lesions and injuries, 681213 drug addiction, ${ }^{68911-14}$ fractures, ${ }^{4}$ pregnancy and parturition, ${ }^{14-16}$ and any procedure involving the blood stream, particularly haemodialysis 91216 and cardiac catheterisation. ${ }^{15}$

Of the 22 patients in whom the alimentary tract seemed to be the portal of entry the causal organisms 
were enterococci, Streptococcus faecalis or Str bovis in 11. Two followed gastroscopy and one followed liver biopsy; in the latter patient the casual organism was Str bovis and malignant disease was probably present. Right hemicolectomy, closure of a colostomy, diverticular disease, rectal carcinoma and adenomas, or polypi of the colon or stomach seemed responsible for seven others. Piles and gall bladder disease and operations for these conditions accounted for another five, while operations for hernia, appendicectomy, oesophageal dilatation, and infections of the gastrointestinal tract were the apparent cause in the remainder. Most of these diseases and procedures have been previously shown to be associated with bacteraemia and infective endocarditis. ${ }^{15-21}$

In 23 patients the infection seemed to come from the genitourinary tract. Enterococci, Str faecalis, coliforms and Proteus or Pseudomonas spp were responsible in 15 of the 23. In five, transurethral or retropubic prostatectomy (one for carcinoma) was responsible, in nine urinary tract infections, in two urethral dilatation, in one nephrectomy for pyelonephritis, in one renal calculus, in one cystoscopy, and in one carcinoma of the bladder. In the female genital tract vaginal hysterectomy, repair of vaginal prolapse, insertion of a ring pessary to control prolapse, and carcinoma of the cervix were each responsible in one patient. Again, the causal association of most of these conditions and procedures with bacteraemia and infective endocarditis have been recorded previously. ${ }^{15} 1722-24$

Fourteen of the 17 patients in whom the respiratory tract was the portal of entry had bronchopulmonary infection. Two of the other three cases followed bronchoscopy and the remaining one developed after a nasal polypectomy in a patient taking steroids. Pneumococcal endocarditis followed the aspiration of a pneumococcal pleural effusion in one patient and developed shortly after bronchoscopy in another, but in many of the remainder the association of respiratory disease or instrumentation and endocarditis may have been temporal rather than causal, although the evidence appears stronger than in many of those of possible dental origin.

In 14 patients the source of infection was the skin. Four patients had gravitational or varicose leg ulcers, five cases followed traumatic skin lesions, and one followed acupuncture; one patient had chronic generalised eczema, one ulcerated rheumatoid nodules, one a septic thumb, and one an infected chest wound after mitral valve replacement.

There were only six drug addicts among the 541 patients, which is fewer than some might anticipate and possibly reflects underrepresentation of hospitals with catchment areas in parts of London and other large cities to which such young people tend to gravi- tate. Five were staphylococcal and one was due to $H$ parainftuenza. None had any pre-existing cardiac disease.

Four cases of infective endocarditis followed fractures, three of which were compound. In the fourth a Colles fracture occurred two months before the onset of infective endocarditis; there was no known previous heart disease and the responsible organism was Str faecalis. The fracture may have been unrelated or the infective endocarditis may have been caused in some way by the anaesthetic, but endocarditis has been reported after closed fractures. ${ }^{4}$

In two patients the endocarditis occurred during pregnancy and in another it followed parturition. This association has been noted by others. ${ }^{15} 1725-27$ In 26 patients the portal of entry was related to cardiac or vascular surgery, cardiac catheterisation, haemodialysis, blood donation, venography, or anticoagulant treatment. In the remaining 326 episodes there was no evidence as to how or where the organisms had entered the blood stream.

Mortality was affected by age, the causative organism, and previous cardiac surgery. The 74 patients who died (Table 3 ) were older (mean age 59.0 years) than those who survived (mean 50.5 years). The mortality was $30 \%$ in staphylococcal infections, $14 \%$ in infections due to bowel organisms, and only $6 \%$ in other streptococcal infections. Other workers 478912 report broadly similar findings. Among the 74 patients who died were five in whom the diagnosis was not made until necropsy and 22 who had had valve replacements or who had undergone other cardiac surgery.

Table 4 shows that $43 \%$ ( 230 of 541 ) of the patients were not known to have any cardiac abnormality before the onset of infective endocarditis. In 59 (26\%) of these 230 patients an undiagnosed pre-existing lesion was undoubtedly present, but in most of the remaini.ng 171 the heart was probably normal; it is possible, however, that in some who recovered without valve replacement a bicuspid aortic valve or degenerative changes in the aortic valve or an unrecognised mitral valve abnormality may have been present. Pre-existing rheumatic heart disease was present in $23.2 \%$, a proportion similar to that in other recent reports, ${ }^{68}$ and the incidence of congenital heart disease was only slightly lower (17.9\%). Among the 141 with other cardiac abnormalities most had mitral incompetence (prolapsing mitral valve) or calcific aortic valve disease.

Table 6 shows the vulnerability of those with prosthetic valves, those who had undergone other cardiac surgery, and those who had previously had infective endocarditis. These three groups comprised $21 \%$ of the patients. The high incidence of infective endocarditis in those with prosthetic valves has been 
emphasised in other reports, 681112 which suggest that the danger is greatest in the early postoperative period, when the organism is usually a staphylococcus. ${ }^{8913}$ Table 7 shows that in this series 77 of the 544 episodes of infective endocarditis were prosthetic valve endocarditis. One seventh occurred during the two months after valve replacement and most of these were staphylococcal. The mortality among them was $45 \%$. In the late cases of prosthetic valve endocarditis staphylococci remained the dominant organism, but three were caused by Coxiella burnetii and the normal microbiological pattern of the disease was more evident. The mortality in late cases was $21 \%$.

Table 5 shows the valve, valves, or other cardiac sites affected by the infective endocarditis. In nearly two fifths it was uncertain or not stated, but where known the aortic valve alone was attacked most often and the mitral valve a little less often.

Infective endocarditis is often difficult to diagnose. Of the 544 episodes studied the diagnosis was not made until operation in four cases and not until necropsy in five others. In addition, 34 of the patients required urgent valve replacement for cardiac or renal failure. There can be little doubt that the best hopes of reducing mortality (which is probably already lower than the widely quoted figure of $30 \%$ ) lie in early diagnosis; close collaboration with microbiologists, and prompt recognition of the need for surgical intervention and many believe that all patients with infective endocarditis should be under the clinical supervision of cardiologists and cardiac surgeons. Certainly, the investigation of murmurs by ultrasound and non-invasive techniques identifies lesions which place patients at special risk such as mitral valve prolapse and bicuspid aortic valves.

An additional difficulty is that bacteraemia if not becoming increasingly common is certainly being recognised more often, and in such patients it may be difficult to be certain whether endocarditis has or has not developed. Fortunately it makes little difference as treatment is unchanged unless valve replacement becomes necessary, by which time cardiac involvement will have been evident at least for some days.

We thank the members of the British Cardiac Society and the fellows and members of the College who participated in this project.

\section{References}

1 Horder TJ. Infective endocarditis with an analysis of 150 cases with special reference to the chronic form of the disease. $Q \mathcal{F}$ Med 1909; 2: 289-324.

2 Cates JE, Christie RV. Subacute bacterial endocarditis: a review of 442 patients in 14 centres appointed by the Penicillin Trials Committee of the Medical Research Council. Qf Med 1951; 20: 93-130.

3 Hughes P, Gauld WR. Bacterial endocarditis: a changing disease. $Q \mathcal{F}$ Med 1966; 35: 511-20.

4 Shinebourne EA, Cripps CM, Hayward GW, Shooter RA. Bacterial endocarditis 1956-65: analysis of clinical features and treatment in relation to prognosis and mortality. Br Heart F 1969; 31: 536-42.

5 Hayward GW. Infective endocarditis: a changing disease. $\operatorname{Br} \mathrm{Med}$ F 1973; ii: 706-9 and 764-6.

6 Schnurr LP, Ball AP, Geddes AM, Gray J, McGhie D. Bacterial endocarditis in England in the 1970s: a review of 70 patients. $Q \mathcal{F}$ Med 1977; 46: 499-512.

7 Lowes JA, Hamer J, Williams G, et al. Ten years of infective endocarditis at St. Bartholomew's Hospital: an analysis of clinical features and treatment in relation to prognosis and mortality. Lancet 1980; i: 133-6.

8 Moulsdale MT, Eykyn SJ, Phillips I. Infective endocarditis, 1970-79: a study of culture positive cases at St. Thomas's Hospital. Qf Med 1980; 49: 315-28.

9 Gray IR. The choice of antibiotic for treating infective endocarditis. $Q \mathcal{F}$ Med 1975; 44: 449-58.

10 Bayliss R, Clarke C, Oakley CM, Somerville W, Whitfield AGW. The teeth and infective endocarditis. Br Heart $\mathcal{F}$ 1983; 50: 506-12.

11 Petersdorf RG, Goldman PL. Changes in the natural history of bacterial endocarditis. F Chronic Dis 1979; 32: 287-91.

12 Pelletier LL Jr, Petersdorf RG. Infective endocarditis: a review of 125 cases from the University of Washington Hospitals 1963-72. Medicine (Baltimore) 1977; 56: 287313.

13 Oakley CM. Infective endocarditis. Br $\mathcal{F}$ Hosp Med 1980; 24: $232-43$.

14 Gray IR. Management of infective endocarditis. $\mathcal{F}$ Coll Physicians Lond 1981; 15: 173-8.

15 Oram S. Clinical heart disease. London: Heinemann, 1981.

16 Everett ED, Hirschmann JV. Transient bacteremia and endocarditis prophylaxis. A review. Medicine (Baltimore) 1977; 56: 61-77.

17 Sipes JN, Thompson RL, Hook EW. Prophylaxis of infective endocarditis: a reevaluation. Annu Rev Med 1977; 28: 371-91.

18 Roses DF, Richman H, Localio SA. Bacterial endocarditis associated with colorectal carcinoma. Ann Surg 1974; 179: 190-1.

19 Lerner PI, Weinstein L. Infective endocarditis in the antibiotic era. $N$ Engl f Med 1966; 274: 199-206.

20 Lefrock JL, Ellis CA, Turchik JB, Weinstein L. Transient bacteremia associated with percutaneous liver biopsy [Abstract]. Clinical Research 1973; 21: 843.

21 Raines DR, Branche WC, Anderson DL, Boyce HW. The occurrence of bacteremia after esophageal dilatation. Gastrointest Endosc 1975; 22: 86-7.

22 Shull HJ, Greene BM, Allen SD, Dunn GD, Schenker S. Bacteremia with upper gastrointestinal endoscopy. Ann Intern Med 1975; 83: 212-4.

23 Mandell GL, Kaye D, Levison ME, Hook EW. Enterococcal endocarditis: an analysis of 38 patients observed at the New York Hospital-Cornell Medical 
Center. Arch Intern Med 1970; 125: 258-64.

24 Sullivan NM, Sutter VL, Mims MM, Marsh VH, Finegold SM. Clinical aspects of bacteremia after manipulation of the genitourinary tract. $\mathcal{F}$ Infect Dis 1973; 127: 49-55.

25 Steyn JH, Logie NJ. Bacteraemia following prostatectomy. Br F Urol 1962; 34: 459-62.

26 Crockett EJ, Batchelor TM, Corbeil J. Pregnancy and subacute bacterial endocarditis: report of a case. Obstet Gynecol 1960; 16: 93-5.
27 Lein JN, Stander RW. Subacute bacterial endocarditis following obstetric and gynecologic procedures. Obstet Gynecol 1959; 13: 568-73.

Requests for reprints to Medical Services Study Group, Royal College of Physicians, 11 St Andrew's Place, London NW1 4LE. 